\title{
Trgovinski rat između Sjedinjenih Američkih Država i Kine
}

\author{
Razlozi, posljedice i etički aspekti rata
}

Anja Tkalčević*, Iva Matić**, Josipa Šegota****

\begin{abstract}
Sažetak
Rad donosi pregled nedavnih protekcionističkih mjera Sjedinjenih Američkih Država (SAD) prema Kini te daje uvid u dvogodišnji trgovinski rat između te dvije države. Analiziraju se postupci i posljedice na svjetsko gospodarstvo. Osim direktnih posljedica na Kinu i SAD, promatra se i neizravan utjecaj na druge zemlje. Promatra se svjetski trend nametanja trgovinskih mjera, njihove prednosti i nedostatci te etičke nedoumice povezane s međunarodnom trgovinskom razmjenom.
\end{abstract}

Ključne riječi: trgovinski rat; SAD; Kina; protekcionizam

\section{Uvod}

Trgovinski rat između SAD-a i Kine gospodarski je sukob između dvije najveće svjetske ekonomije i, sve od početka 2018. godine, najpraćeniji globalni sukob. Bivši predsjednik SAD-a Donald Trump u 2018. godini započeo je s uvođenjem trgovinskih barijera Kini s ciljem zaštite američke industrije (prvenstveno tehnološki napredne industrije), pri čemu neki autori ističu i druge, političke ciljeve trgovinskoga rata. Spomenuti trgovinski rat nije imao velik utjecaj samo na proizvođače i potrošače u navedenim zemljama, nego i na sve ostale zemlje preko globalnih trgovinskih lanaca. Pritom je manji broj zemalja profitirao povećavajući proizvodnju i popunjavajući prazninu na tržištu koja je izazvana restrikcijama,

* Anja Tkalčević, MBA. Zagrebačka škola ekonomije i managementa. Adresa: Vukasovićeva ulica 1, 10000 Zagreb, Hrvatska. Hrvatska agencija za nadzor financijskih institucija HANFA. Adresa Ul. Franje Račkoga 6, 10000 Zagreb, Hrvatska. ORCID iD: https://orcid.org/0000-0003-41241399. E-adresa: aristic@zsem.hr. Stavovi izneseni u tekstu osobni su stavovi autora te ne odražavaju nužno stav agencije.

** Iva Matić, Zagrebačka škola ekonomije i managementa. Adresa: Vukasovićeva ulica 1, 10000 Zagreb, Hrvatska. ORCID iD: https://orcid.org/0000-0001-5816-6669. E-adresa: imatic@student.zsem.hr

*** Josipa Šegota, bacc. oec., Zagrebačka škola ekonomije i managementa. Adresa: Vukasovićeva ulica 1, 10000 Zagreb, Hrvatska. Poslovna akademija d.o.o. Jandrićeva 12, 10000 Zagreb. ORCID iD: https://orcid.org/0000-0001-8744-6002. E-adresa: jsegota@zsem.hr 
a veći je broj zemalja snosio negativne posljedice. Trgovinske restrikcije dovele su i do nestabilnosti na burzama, odnosno tržištima kapitala. Vlade nekoliko zemalja, uključujući one SAD-a i Kine, poduzele su određene mjere kako bi pokušale ublažiti dio štete uzrokovane pogoršanim trgovinskim i političkim odnosima.

U nastavku rada prikazuje se tijek trgovinskoga rata, njegov utjecaj na gospodarstva SAD-a i Kine, ali i utjecaj na međunarodnu ekonomiju. U ovom radu ispituje se i etičnost trgovinskoga rata SAD-a i Kine. Glavna nedoumica odnosi se tako na upitnost moralnosti međunarodne politike SAD-a predvođene predsjednikom Trumpom, koja koristi domaćim proizvođačima, ali šteti potrošačima te remeti slobodnu trgovinu na međunarodnoj razini.

\section{SAD kao predvodnik rasta protekcionizma}

Jedna od temeljnih poruka u predsjedničkoj kampanji, koju je američkim biračima poslao tadašnji kandidat za predsjednika Donald Trump, bila je zaštita domaće industrije od, po njemu, nelojalne inozemne konkurencije (Evans, 2019). Nakon inauguracije u siječnju 2017. godine, Trump je obećao kako će vrlo brzo započeti s realizacijom svojega plana o zaštiti američke industrije - i nije prevario birače.

Prvi poduzeti korak odnosio se je tako na povlačenje SAD-a iz trgovinskoga sporazuma Trans-Pacific Partnership (TPP), koji su trebale ratificirati SAD, Australija, Kanada, Novi Zeland, Japan, Meksiko, Malezija, Peru, Singapur, Vijetnam, Bruneji i Čile. Vrlo brzo uslijedio je zahtjev za redefiniranjem odnosa u jednom od najpoznatijih svjetskih trgovinskih sporazuma - North American Free Trade Agreement (NAFTA) — koji su 1994. potpisale susjedne SAD, Kanada i Meksiko. Navedene zemlje potpisale su novi trgovinski sporazum kako bi zamijenile NAFTA-u. Neke od najvećih predloženih izmjena obuhvaćenih u novom United States-Mexico-Canada Agreement (USMCA) ili NAFTA 2 sporazuma (za sada ratificiranoga samo u meksičkom parlamentu) u odnosu na stari NAFTA sporazum obuhvaćaju (USTR, 2020):

a) Uvjet lokalnoga sadržaja: automobili moraju sadržavati $75 \%$ komponenti proizvedenih u Meksiku, SAD-u ili Kanadi kako bi se kvalificirali za nultu carinsku stopu (prije u NAFTA-i referentna je vrijednost domaćega sadržaja iznosila $62,5 \%)$.

b) Radničke odredbe: $40 \%$ do $45 \%$ automobilskih dijelova moraju izrađivati radnici koji će do 2023. godine zarađivati najmanje 16 američkih dolara po satu. Meksiko je također pristao donijeti zakone koji radnicima daju pravo na sindikalno zastupanje, proširiti radnu zaštitu na radnike migrante i zaštititi žene od diskriminacije. Zemlje se mogu međusobno sankcionirati zbog kršenja radnih odredbi.

c) Poljoprivreda: Američki poljoprivrednici dobili su veći pristup kanadskomu tržištu mliječnih proizvoda, što je gospodarstvu SAD-a od velike važnosti. Do tada je uvoz američkih mliječnih proizvoda u Kanadu nakon dosezanja odre- 
đene kvote bio podvrgnut carinama između 241-300\%, što je predsjednik Trump smatrao diskriminacijom američkih mljekara i farmera (Northam, 2018).

d) Intelektualno vlasništvo i digitalna trgovina: Taj sporazum produžuje uvjete priznavanja i iskorištavanja autorskih prava na 70 godina nakon smrti autora, za razliku od prijašnjih 50. Također, produžuje se razdoblje u kojem se farmaceutski lijek može zaštititi od generičke konkurencije.

U međuvremenu je predsjednik Trump ugrozio rad najvažnije globalne institucije koja regulira trgovinske odnose između zemalja — Svjetsku trgovinsku organizaciju (World Trade Organisation, WTO) - stavljanjem veta na izbor članova Odbora za rješavanje sporova (Dispute Settlement Body), tijela koje je zaduženo za trgovinske sporove među zemljama (Johnson, 2019). U 2018. godini američka administracija započela je i s uvođenjem carina. U siječnju te godine uvedene su carine na solarne panele i perilice rublja. U ožujku je uvedena 25postotna carina na uvoz čelika i 10-postotna carina na uvoz aluminija, čime su najviše bile pogođene Kina i Brazil (Bown i Kolb, 2020). Od lipnja iste godine te su carine bile primjenjivane i na zemlje Europske unije, Kanadu i Meksiko, a ubrzo i na sve zemlje s kojima SAD posluje, izuzev Argentine, Australije, Brazila i Južne Koreje vezano uz američki uvoz čelika te Argentine i Australije u slučaju razmjene aluminija. Europska unija (EU) na taj je potez odgovorila protumjerom. U lipnju 2018. godine Europska unija uvela je 25-postotnu carinu na uvoz američkih proizvoda (sok od naranče, burbon, traperice i motocikli) ukupne vrijednosti 2,8 milijardi eura (Bown, 2018a). Kina je protumjerama uzvratila još i ranije. Početkom travnja 2018. godine Kina je uvela carine koje variraju između $15 \%$ i $25 \%$ na 128 američkih proizvoda, uključujući, velikim dijelom, voće, vino, svinjetinu, čelične cijevi i reciklirani aluminij (Wong i Chipman Koty, 2020). Mjesec travanj 2018. godine obilježen je brojnim prijetnjama jedne velesile drugoj i međusobnim odgovorima. SAD je predložio listu 1.334 kineskih proizvoda koji bi potencijalno mogli biti izloženi carini od 25\%, ukupne vrijednosti 50 milijardi američkih dolara, što je SAD nazvao odgovorom na nepoštene poslovne i trgovačke prakse Kine u prošlosti, pretežito se fokusirajući na kršenje prava intelektualnoga vlasništva (USTR, 2019). Kina je na to uzvratila protunapadom te je predložila vlastitu listu u jednakoj vrijednosti kao ona koju je sastavio SAD, a koja sadrži 106 američkih proizvoda, među ostalim sjemenke soje, automobile i kemikalije, koji bi također mogli biti izloženi carini od 25\% (Wong i Chipman Koty, 2020).

Sve je dodatno eskaliralo kada je SAD zabranio američkim kompanijama poslovanje s kineskim telekomunikacijskim divom Zhongxing Telecommunication Equipment Corporationn (ZTE) što je dovelo do trgovinskih pregovora koji su trajali tijekom svibnja 2018., nakon čega je uslijedilo kratko primirje, tijekom kojega je odobren nastavak poslovanja ZTE u SAD-u.

Sredinom lipnja 2018. provedeni su prethodno najavljeni carinski planovi, no s reduciranom listom proizvoda. U kolovozu 2018. godine SAD je povećao carine na čelik i aluminij Turskoj te su u istom periodu SAD i Kina ušle u drugi krug nametanja carina u međusobnoj vrijednosti od 16 milijardi američkih dolara (Wong 
i Chipman Koty, 2020). Osim toga, Kina je podnijela žalbu Svjetskoj trgovinskoj organizaciji ističući da su carine na solarne panele koje je uveo SAD prekršile pravila WTO-a i destabilizirale tržište fotonaponskih proizvoda, naštetivši kineskim trgovinskim interesima.

Sukob je eskalirao u rujnu iste godine kada su se počele primjenjivati sve prethodno najavljene prijetnje, odnosno kada je SAD uveo carine na kineske proizvode $u$ vrijednosti od 200 milijardi američkih dolara. Kina je na to odgovorila carinama na američku robu u vrijednosti od 60 milijardi američkih dolara, što predstavlja treći krug podizanja carina (Bown, 2018c). SAD je najavio novo podizanje carinskih stopa s $10 \%$ na $25 \%$ ako Kina zaista odluči poduzeti najavljene protumjere u navedenom posljednjem krugu nadmetanja, ali prijetnje su ostale neostvarene - u prosincu 2018. godine dvije zemlje najavile su 90-dnevno primirje obilježeno brojnim pokušajima pregovora (Wong i Chipman Koty, 2020).

Iako su u travnju 2019. godine postojale naznake za smirivanje tenzija između SAD-a i Kine — kada su vođeni razgovori o osnivanju posebnoga Ureda za provedbu dogovora o trgovini - SAD je u svibnju, samo mjesec dana nakon toga, podignuo carine s $10 \%$ na 25\% (Wong i Chipman Koty, 2020). Tada je uslijedio val podizanja carina i zabrana. 13. svibnja 2019. godine Kina je najavila podizanje carina (uz izuzeća), a tri dana kasnije, 16. svibnja, SAD je stavio kineskoga tehnološkoga magnata Huawei na svoju "crnu listu", te je zabranio američkim kompanijama da kupuju Huawei proizvode. Na to je Kina odgovorila 1. lipnja povećavši carine na proizvode u vrijednosti 60 milijardi američkih dolara i stvaranjem vlastite liste nepodobnih američkih poduzeća koja se na kineskom tržištu ne pridržavaju tržišnih pravila, krše ugovore ili nanose neku drugu vrstu štete kineskomu gospodarstvu (Bown, 2018c).

Zadnja runda podizanja carina na kineski uvoz odnosila se je na sve proizvode od mesnih prerađevina do glazbala, i to s carinom od $15 \%$, čime je carinjen gotovo sav kineski uvoz. Peking je uzvratio carinama na američka dobra u rasponu od $5 \%$ do $15 \%$. Posljednji udar na carine uključivao je 5-postotnu tarifu na američku sirovu naftu, što je prvi put u povijesti da je gorivo uključeno u trgovinski rat (Wong i Chipman Koty, 2020).

U jesen 2019. godine naziru se elementi koju upućuje na ublažavanje trgovinskoga rata. Mnoge prijetnje SAD-a o uvođenju još carina te povećavanju postojećih s $25 \%$ na $30 \%$ nisu se ostvarile (Wong i Chipman Koty, 2020). Štoviše, u listopadu 2019. godine započela je prva faza pregovora o potpisivanju zajedničkoga dokumenta o trgovinskom dogovoru, koji je u siječnju 2020. godine i potpisan. Spomenutim dogovorom Kina se je obvezala na uvoz 200 milijardi dolara američke robe u naredne dvije godine, a SAD je pristao "prepoloviti" navedene carinske stope na robu kineskoga podrijetla (Bown, 2018c). Novi globalni ekonomski šok bez presedana, odnosno pandemija korona virusa, restriktivne epidemiološke mjere za njezino suzbijanje i posljedično snažan pad bruto domaćega proizvoda čine tijek i ishod pokrenutoga trgovinskoga sporazuma između SAD i Kine vrlo neizvjesnim. 
Uvažavajući sve ranije istaknute trgovinske namete, ograničenja i dogovore, ukupna vrijednost američke carine primijenjena na isključivo kinesku robu iznosi 550 milijardi američkih dolara, a ukupna vrijednost kineske carine primijenjene na isključivo američku robu iznosi 185 milijardi američkih dolara (Wong i Chipman Koty, 2020). Tijek trgovinskoga rata između Kine i SAD-a detaljno je prikazan na Slici 1.

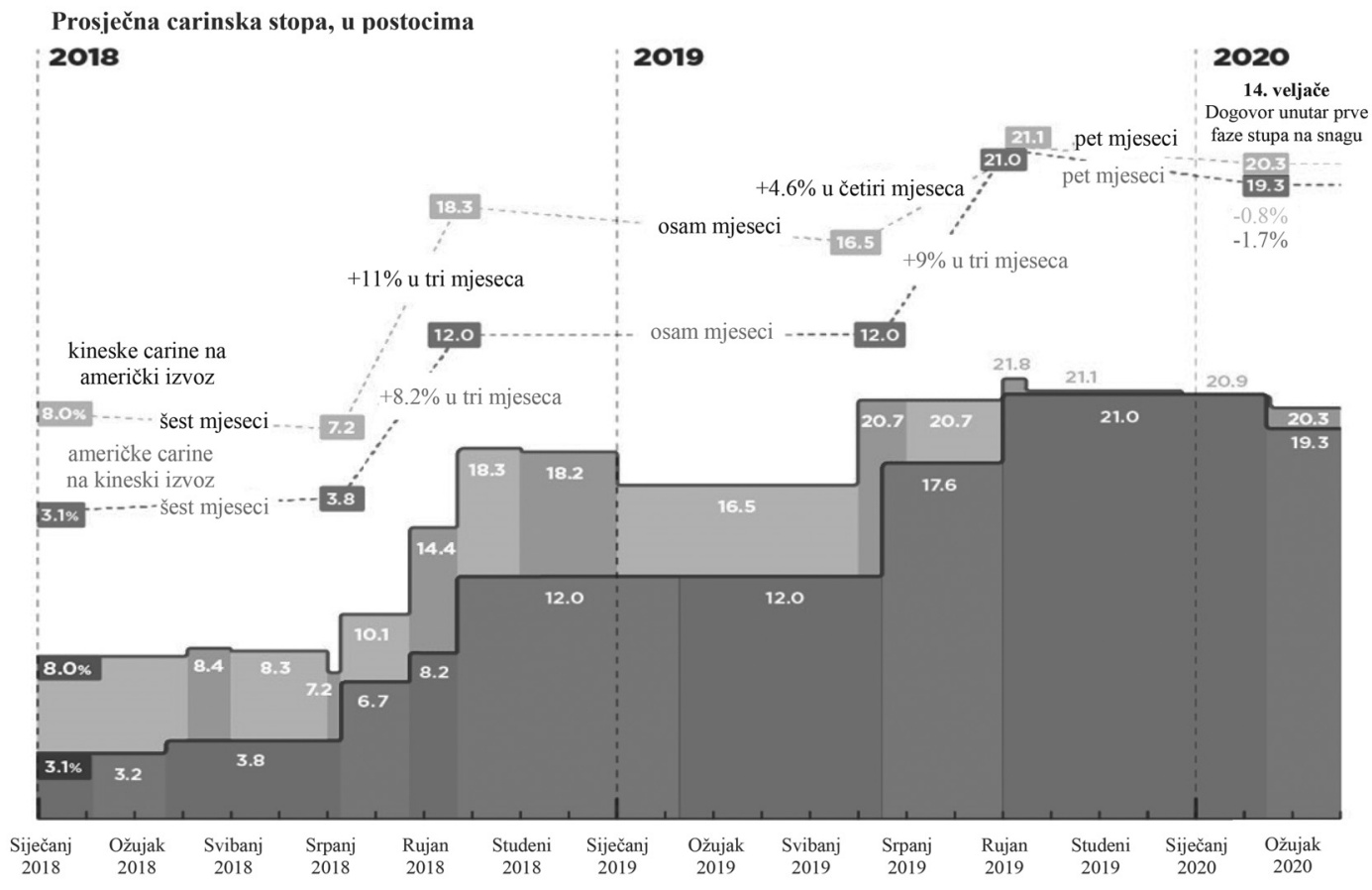

Slika 1. Tijek trgovinskog rata između SAD-a i Kine

Image 1. The course of the US-China trade war

Izvor: Bown, Chad P. 2019. US-China TradeWarTariffs: An Up-to-Date Chart, Washington: Peterson Institute for International Economics. Dostupno na https:/www.piie.com/research/piie-charts/ us-china-trade-war-tariffs-date-chart . Pristupljeno 25.10.2020.

Source: Bown, Chad P. 2019. US-China TradeWarTariffs: An Up-to-Date Chart, Washington: Peterson Institute for International Economics. Available at https://www.piie.com/research/piie-charts/us-chinatrade-war-tariffs-date-chart. Accessed on 10/25/2020.

Zemlje Europske unije, Kina, Turska i većina drugih zemalja odgovorile su protumjerama, pa se trenutačna situacija u svjetskoj trgovini često naziva trgovinskim ratom (eng. tradewar) koji će imati neizvjesne posljedice za zemlje koje su direktno u njega uključene, ali i za one koje nisu. Trgovinski rat SAD-a i Kine neće imati veliki utjecaj na Hrvatsku, a jedan od glavnih razloga zbog čega je to slučaj taj je da Hrvatska ima neznatan udio u svjetskom vrijednosnom lancu te zbog toga ne bi trebala biti pogođena svim navedenim restrikcijama u trgovini. 
Analitičari tvrde kako kriza uzrokovana koronavirusom ubrzava razdvajanje Kine i SAD-a više nego što je to učinio njihov trgovinski rat — demonstrirajući SAD-u vrijednost diverzifikacije trgovinskoga i investicijskoga poslovanja izvan Kine.

U prvoj fazi trgovinskoga sporazuma, potpisanoj u siječnju ove godine, Kina se je obvezala na uvoz 200 milijardi dolara američke robe u naredne dvije godine, a SAD je pristao "prepoloviti" prethodno navedene carinske stope na robu kineskoga podrijetla. Međutim, međunarodna situacija uzrokovana novonastalom koronakrizom dovodi u pitanje mogućnost ostvarenja postignutih dogovora, a tijek i ishod pokrenutoga trgovinskoga sporazuma ostaju neizvjesni.

Trenutačno je kineski uvoz američke robe, energije i usluga uvelike zaostao $\mathrm{u}$ ispunjavanju sporazumom dogovorenih obveza. U prvoj polovici 2020. godine Kina je kupila manje od četvrtine ciljane godišnje količine američke robe. Taj zaostatak djelomično se može objasniti upravo utjecajem koji koronakriza ima na svjetsku ekonomiju, točnije usporavanjem međunarodnih trgovinskih puteva, ugroženim lancima opskrbe, padom potražnje u Kini te iščekivanjem recesije. S obzirom na novonastalu situaciju, predstavnici zemalja odlučili su odgoditi zajednički osvrt na prvu fazu dogovora te pregovore o drugoj fazi, koja je postala upitna nakon sučeljavanja predsjednika po pitanju pandemije Covid-19. Američki predsjednik Donald Trump optužio je Kinu za pokretanje "pošasti” u svijetu i zatražio da preuzme odgovornost pred Ujedinjenim narodima (UN), na što je njegov kineska kolega Xi Jinping odgovorio kako je borba protiv virusa prilika za međunarodnu suradnju. Trumpovo mišljenje dijele i njegovi brojni sunarodnjaci. Prema istraživanju Pew Research Center provedenom u ožujku, otprilike dvije trećine Amerikanaca ima negativan stav prema Kini, s porastom od gotovo $20 \%$ od početka Trumpove administracije.

Međutim, s obzirom na nedavnu pobjedu Joea Bidena na predsjedničkim izborima, američki pristup Kini vjerojatno će se uravnotežiti te će se povećati šanse za nastavak trgovinskih pregovora i suradnje po pitanju ekonomskih nestabilnosti uzrokovanih pandemijom Covid-19.

\section{Razlozi za trgovinski rat između SAD-a i Kine}

Jedan od osnovnih razloga trgovinskoga rata proizlazi iz rastućega trgovinskoga deficita SAD-a u odnosu na Kinu, što je prikazano na Slici 2. Tamni stupci predstavljaju uvoz i izvoz robe iz Kine u SAD, a svijetli stupci predstavljaju uvoz i izvoz američkih roba i usluga u Kinu. Iz Slike 2 razvidno je da Kina puno više izvozi u SAD nego što iz SAD-a uvozi, a SAD puno više proizvoda i usluga iz Kine uvozi nego što u Kinu izvozi. Pritom je predsjednik Trump uvjeren kako je takva situacija najvećim dijelom posljedica privilegirane pozicije Kine u WTO-u te manipulacije tečajem RMB/USD, a ne strukturnih manjkavosti gospodarstva SAD-a (Liu i Woo, 2018). 


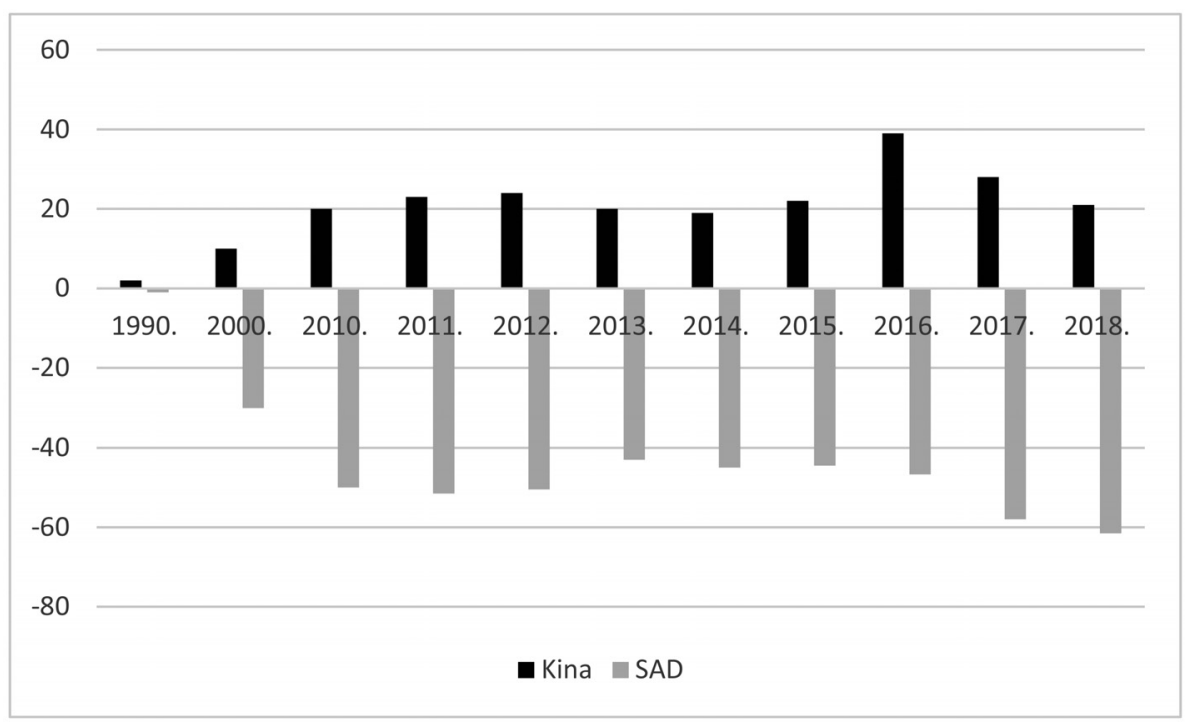

Slika 2. Neto razmjena dobara i usluga, u mlrd. US\$

Image 2. Net exchange of goods and services, in bn.US\$

Izvor: Izradili autori prema Statista (2019). Dostupno na: https://www.statista.com/statistics/939402/ us-china-trade-deficit/ Pristupljeno 23.4. 2020

Source: Compiled by the authors according to Statista (2019). Available at: https://www.statista.com/ statistics/939402/us-china-trade-deficit/Accessed on 4/23/2020

Struktura vanjskotrgovinskih tokova između dviju ekonomskih sila prikazana na Slici 3 otkriva još jednu važnu činjenicu. Uvoz Kine iz SAD-a velikim se dijelom odnosi na kapitalna dobra i strojeve, pri čemu predsjednik Trump ističe da je intelektualno vlasništvo i tehnološki napredne obrasce poslovanja Kina preuzimanjem tih tvrtki kupila po cijeni koja ne odražava tržišnu (stvarnu) vrijednost. 


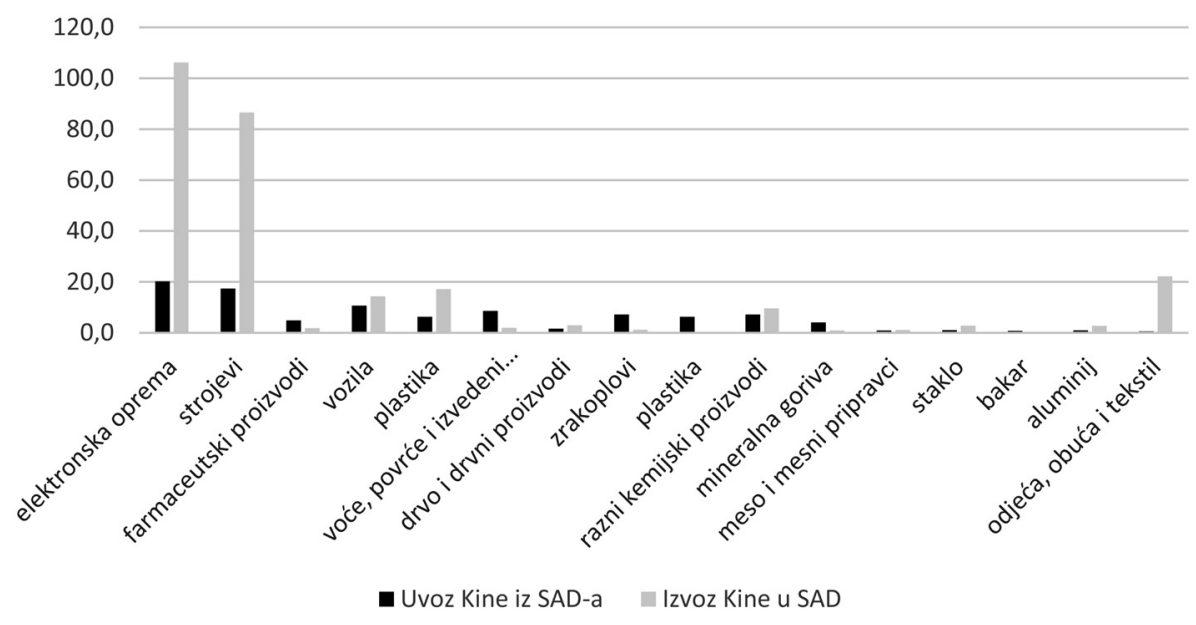

Slika 3. Struktura trgovine SAD-a i Kine, u mlrd. US\$ Image 3. The trade structure between the USA and China, in bn. US\$

Izvor: Izradili autori prema ITC (International Trade Center) (2020). Dostupno na https://www.intracen.org/itc/market-info-tools/statistics-import-country-product/ Pristupljeno 25.10.2020

Source: Compiled by authors according to ITC (International Trade Center) (2020). Available at https:// www.intracen.org/itc/market-info-tools/statistics-import-country-product/Accessed on 10/25/2020

Jedan od razloga zašto predsjednik Trump nameće carine spoznaja je da Kina kroz kupnju i preuzimanja kompanija dolazi do napredne tehnologije za koju nije platila poštenu pripadajuću cijenu (Bown, 2018b). Na tom je tragu i izvještaj koji je u lipnju 2018. godine izdao Ured Bijele kuće za trgovinu i proizvodnju, u kojem je navedeno da Kina ima cilj preuzeti ključne tehnologije i intelektualno vlasništvo drugih zemalja, uključujući i SAD-a, te tim preuzimanjem osigurati pristup najnaprednijim tehnologijama koje su pokretači budućega ekonomskoga rasta, ali i probitaka u vojnoj industriji.

$\mathrm{U}$ raspravama o učincima trgovinskoga protekcionizma često se upada u zamku analiza "ekonomije s dvije varijable". U tim raspravama svijet se gleda crno-bijelo i slijedi se logika "ako nije A onda vrijedi B". Međutim, stvarni ekonomski odnosi vrlo su kompleksni i nikada se ni jedna mjera ekonomske politike ne može gledati isključivo kroz prizmu jednoga cilja koji se želi postići, nego se moraju sagledati sve željene, ali i potencijalne neželjene posljedice tih mjera (Li et al., 2018).

Razmišljanje da će podizanje postojećih ili isticanje novih carina na primjerice aluminij i čelik sigurno biti povoljno za kumuliranje BDP-a američkoga gospodarstva, koje iste također proizvodi, ne uzima u obzir cijeli niz mehanizama koji naposljetku mogu djelovati štetno ne samo na američko gospodarstvo, nego i na ostatak svijeta.

Tako bi veće uvozne cijene mogle povećati troškove proizvodnje i smanjiti kupovnu moć kućanstava, što bi se moglo negativno odraziti na potrošnju, investi- 
cije i zaposlenost. Eskalacijom trgovinskih napetosti povećala bi se gospodarska neizvjesnost, što dovodi do odgađanja potrošnje i ulaganja. Kao odgovor na veću nesigurnost, financijski investitori mogli bi smanjiti izloženost tržištu kapitala te zahtijevati veću premiju za preuzeti rizik. To naposljetku može povećati kolebljivost na financijskim tržištima, a u bankarskom sektoru smanjiti ponudu kredita i/ili povećati troškove zaduživanja (kamate). Potiskujući rast proizvodnosti rada, protekcionizam dugoročno negativno utječe na potencijalni gospodarski rast. Druge su zemlje neizravno pogođene slabijom potražnjom za vlastitim izvozom, bilo kroz opskrbne lance, bilo kao odgovor na slabiji svjetski ekonomski rast. Potonji učinci gotovo uvijek nadmašuju probitke koje pojedinačne zemlje ostvaruju od zaštite koju carine pružaju domaćoj proizvodnji. U protekcionističkom scenariju razina rasta globalnoga realnoga BDP-a je 2018. godine smanjena za 0,1 postotnih bodova, za 0,8 postotnih bodova u 2019. te za 1,4 postotna boda $\mathrm{u}$ 2020. godini. Dakle, rast globalne ekonomije u 2019. i 2020. samo je malo iznad našega praga od $2 \%$ za svjetsku recesiju (Tam, 2019).

Treba također istaknuti da su razlozi trgovinskih mjera koje je Kini nametnuo SAD dijelom vezani i uz promišljanje američke administracije da Kina manipulira svojom valutom na način da ju namjerno podcjenjuje te tako povećava svoju globalnu konkurentnost: »Trgovinski rat postao je valutni rat, što potencijalnu ekonomsku štetu podiže na drugu razinu« (Editorial Board, 2019).

Kada je riječ o burzovnim kretanjima, promatrajući S\&P 500, Nasdaq i Russell 2000 u usporedbi sa Shanghai Composite, moguće je zaključiti kako se tržište dionica u SAD-u od trgovinskoga rata oporavlja mnogo bolje nego kinesko tržište dionica, ostvarujući bolje rezultate za vrijeme trajanja trgovinskoga nadmetanja, ali i rekordan rast od trenutka naziranja primirja i mogućnosti ostvarenja trgovinskoga sporazuma pa sve do sredine veljače, kada je tržište pretrpjelo novi udarac, koji je nastao kao posljedica pandemije Covid-19. Zanimljivo je kako su izravni učinci podizanja carina u SAD-u imale veći negativan utjecaj na domaće tržište dionica nego na kinesko, što je bilo potpuno neočekivano: pokušavajući zaštiti domaću ekonomiju, SAD joj je nenamjerno nanio više štete nego ekonomiji kojoj je ciljao naštetiti (Egger i Zhu, 2019, 16).

Pokazalo se je da su neto negativni izravni učinci trgovinskoga rata najviši za američke tvrtke, pri čemu su neizravni učinci izazvani američkim promjenama carina veći od onih izazvanih promjenama u kineskoj carinskoj politici, što se najvećim dijelom očituje kroz globalne vrijednosne lance. Općenito, promjene carina u SAD-u, pa čak i sama njihova najava, imala je negativniji neizravni učinak na treće zemlje nego što je to imala promjena carina u Kini (Egger i Zhu, 2020).

Osim deviznoga i dioničkoga tržišta gubitke je pretrpjelo i svjetsko tržište kapitala. Naime, u prvoj polovici 2018. godine kineska inozemna izravna ulaganja u SAD-u iznosila su 1,8 milijardi američkih dolara, što je smanjenje od $90 \%$ $\mathrm{u}$ usporedbi s istim razdobljem prethodne godine te predstavlja najnižu razinu ulaganja još od 2011. godine. Kineski ulagači koji su prethodno investirali unutar SAD-a počeli su povlačiti svoja financijska sredstva iz zemlje, što je za SAD predstavljalo gubitak od 10 milijardi američkih dolara u prvih pet mjeseci 2018. 
godine (Putz et al., 2018). Zbog povećanja regulatornih zahtjeva, s problemima bi se u SAD-u mogle suočiti i mlade američke tvrtke koje se poglavito oslanjaju na napredne informatičke tehnologije (eng. start-up), u koje su zamjetna financijska sredstva ulagali upravo kineski investitori.

\section{Protekcionizam kao američka specifičnost}

Iako je ova tema došla u fokus medija tijekom predsjedničke kampanje Donalda Trumpa, važno je napomenuti kako se rast protekcionizma bilježi još od eskalacije globalne financijske krize. Mnoge zemlje u svijetu pokušale su ublažiti recesiju koja je pogodila domaća gospodarstva uvođenjem nekoga oblika protekcionističkih mjera. Primjerice, neke europske zemlje mijenjale su i pooštrile standarde za određene proizvode, što također predstavlja jedan od oblika protekcionizma. Takvi posebni oblici prepreka trgovini u stalnom su porastu već cijelo desetljeće, što se može vidjeti iz broja otvorenih rasprava na tu temu na sastancima WTO-a. Kretanje reakcija na uvođenje novih oblika trgovinske zaštite prikazano je na Slici 4.

Prema izvještajima WTO-a, od 2008. do 2016. njegove su članice uvele 2,835 različitih restriktivnih mjera, a pritom ukinule samo njih 708. Na Slici 4 prikazano je kretanje svih trgovinskih mjera u razvijenim zemljama, odnosno članicama skupine G20. Iz navedenoga prikaza jasno je vidljiv neprestani porast broja restrikcija, pogotovo u razdoblju nakon 2008. godine.

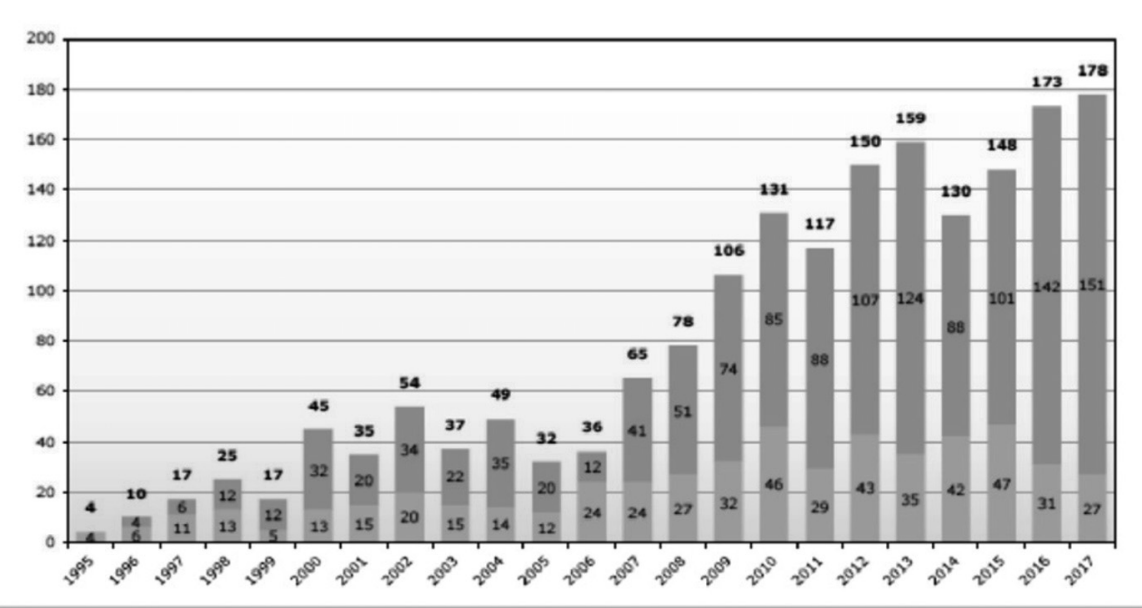

Slika 4. Broj posebnih trgovinskih prijepornih slučajeva Image 4. Number of special cases of trade concerns

Izvor: Svjetska trgovinska organizacija (2018.) Dostupno na https://www.wto.org/english/news_e/ news18_e/trdev_25jul18_e.htm. Pristupljeno 25.6.2020

Source: World Trade Organisation (2018) Available at https://www.wto.org/english/news_e/news18_e/ trdev_25jul18_e.htm. Accessed on 06/25/2020 
Još je zanimljivije promotriti kretanje uvedenih restrikcija u razdoblju od 2009. do 2017. godine na Slici 5. Zatamnjeni stupci prikazuju kretanje broja uvedenih štetnih trgovinskih restrikcija, a svijetli stupci prikazuju broj uvedenih oslobađajućih trgovinskih mjera. Jasno je vidljivo da je broj štetnih trgovinskih mjera zamjetno veći od oslobađajućih, i to tijekom cijeloga spomenutoga razdoblja. Također, može se primijetiti da broj oslobađajućih trgovinskih mjera stagnira od 2013. godine, a broj je štetnih trgovinskih mjera u porastu.

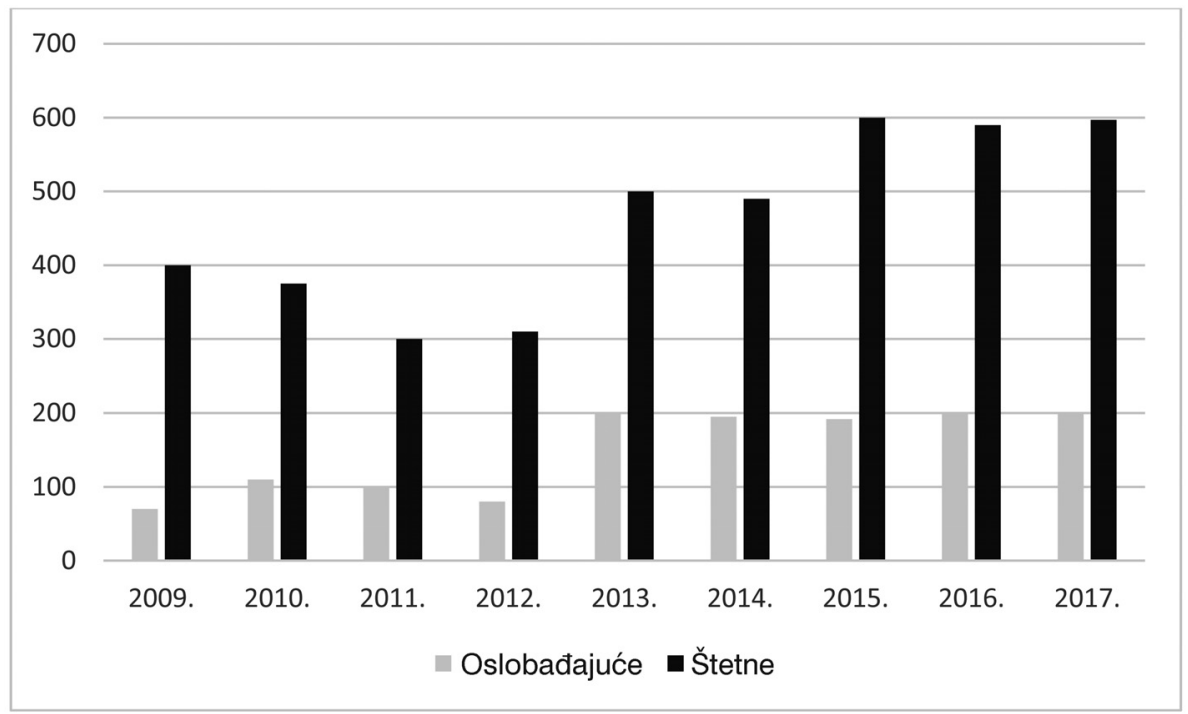

Slika 5. Broj poduzetih trgovinskih mjera

Image 5. Number of implemented trade measures

Izvor: Izradili autori prema ECB (2018). Dostupno na https://www.ecb.europa.eu/pub/pdf/other/ecb. ebbox201803_01.en.pdf. Pristupljeno 24.4.2020

Source: Compiled by the authors according to ECB (2018). Available at https://www.ecb.europa.eu/pub/ pdf/other/ecb.ebbox201803_01.en.pdf. Accessed on 4/24/2020

Dakle, iako se SAD čini predvodnikom rasta protekcionizma, ne treba zaboraviti da su i ostale zemlje (u prvom redu Indija, Rusija, Brazil i Kina, kao i zemlje Europske unije) u posljednjih desetak godina uvele niz mjera usmjerenih na zaštitu domaće industrije.

Naime, protekcionističku politiku SAD-a definiraju transparentni carinski nameti i novčana ograničenja, a ostala se gospodarstva više oslanjaju na suptilnije načine provedbe protekcionizma pomoću raznih necarinskih ograničenja, ${ }^{1}$ čime izbjegavaju neželjenu medijsku pažnju. Iako je općenito došlo do smanjenja trgovinskih barijera, valja uzeti u obzir da se ta smanjenja uglavnom odnose na carinske barijere, koje aktivno obeshrabruje WTO, što potencijalno potiče isticanje necarinskih barijera, a time i smanjenje obujma svjetske trgovine.

1 Kvote, nameti, embargo i sankcije. 


\section{Etičnost trgovinskih ratova}

Iako su suvremene metode komunikacije i prijevoza zamjetno pridonijele stvaranju integriranoga globalnoga gospodarstva, povijest je pokazala da politički čimbenici ponekad mogu djelovati snažnije od tehnoloških čimbenika. Nositelji ekonomskih politika često su zabrinuti (ili žele ostaviti takav dojam pred biračkim tijelom) kakav učinak međunarodna trgovina ima na domaće industrije te su ih nerijetko pokušavali zaštiti uvođenjem uvoznih ograničenja ili davanjem izvoznih potpora. Dapače, neka od najvećih svjetskih tržišnih gospodarstava na svijetu (SAD, Njemačka i Japan) započela su industrijalizaciju upravo uvođenjem tržišnih ograničenja. Po uzoru na njih, brojne države i danas naginju protekcionizmu, osobito zaštiti mladih industrija koje se u početku ne mogu suprotstaviti snažnoj inozemnoj konkurenciji. Pritom se nameće pitanje je li taj argument opravdan i etički prihvatljiv? Nadalje, promatrajući slučajeve zemalja u razvoju koje su poticale industrijalizaciju nadomještanjem i potiskivanjem uvoza, može se primijetiti kako su barijere slobodnoj trgovini potaknule rast proizvodnje domaćih supstituta uvoza. Znači li to da su protekcionističke mjere poželjne jer su polučile takav učinak? Je li iste pratio i odgovarajući rast realnoga BDP-a po stanovniku, odnosno realne konvergencije? Ekonomska je povijest pokazala da takve zemlje nisu rasle dovoljno brzo da bi se natjecale s naprednim zemljama niti su ostvarile bitan gospodarski razvoj u usporedbi sa zemljama koje nisu koristile protekcionističke mjere (Krugman i Obstfeld, 2009). Naposljetku, treba naglasiti da je globalizacija otvorila vrata slobodnoj trgovini, čije su mogućnosti i prednosti neiscrpne u usporedbi sa zatvorenim ekonomijama, zbog čega bi se trgovinska liberalizacija trebala gorljivo poticati (Wight, 2018; Gvosdev 2019).

Vodeće međunarodne institucije (MMF, WTO, OECD) ističu dobrobiti trgovinske liberalizacije, koje se ogledaju u: a) postizanju bolje alokacije ograničenih resursa; b) korištenju prednosti ekonomija obujma; c) lakšem prijenosu naprednih znanja i tehnologija; d) rastu konkurencije na domaćem i inozemnim tržištima; e) pozitivnom utjecaju na rast proizvodnosti rada, a time i dugoročnom potencijalnom rastu realnoga BDP-a.

Spomenute institucije pozivaju zemlje da probleme s konkurentnošću domaćih kompanija rješavaju strukturnim reformama, a ne zatvaranjem granica te ističu da protekcionističke politike treba izbjegavati jer vjerojatno neće smanjiti vanjske neravnoteže, a istodobno će naškoditi gospodarskomu rastu.

Ekonomisti i donositelji međunarodnih politika razmatraju etičnost započinjanja trgovinskoga rata. Tu se javlja više moralnih dvojbi. Uzmimo za primjer povećanje carina na uvoz čelika. SAD je povisio carine na uvoz čelika opravdavajući taj potez boljim uvjetima za 140 tisuća američkih radnika zaposlenih u sektoru proizvodnje čelika. Međutim, što je s 6,5 milijuna Amerikanaca koji koriste čelik kao intermedijarno dobro u proizvodnji drugih finalnih dobara te s preostalih 300 milijuna američkih potrošača koji kupuju čelik u nekom obliku? Pitanje je koja će strana imati prioritet u moralnom odlučivanju. Je li etički ispravno pomoći pojedinim domaćim tvrtkama da se bore protiv međunarodne konkurencije, a istovremeno svaliti teret carina i, posljedično, viših cijena čelika 
u zemlji na potrošače? Političke se odluke zato nerijetko povezuju s gospodarskim uspjesima, odnosno rastom makroekonomskih pokazatelja, a odluka je o tom tko će donijeti takve važne politike na glasačima koji biraju izvršnu vlast. Zato se brojne mjere trgovinske politike, između ostaloga, donose kako bi političari osigurali pobjedu u narednom političkom ciklusu.

Jednako tako, ekonomske studije dokazale su negativan utjecaj trgovinske razmjene (pogotovo s Kinom) na zaposlenost u SAD-u. Zbog pristupanja Kine Svjetskoj trgovinskoj organizaciji Amerikanci su izgubili gotovo milijun radnih mjesta u sektoru proizvodnje, a od 1999. godine do danas gubitak radnih mjesta zbog povećane trgovine s Kinom procjenjuje se na 1,75 milijuna. Međutim, postoje brojne druge mjere (kao alternativa protekcionizmu) koje mogu polučiti dobre rezultate bez uzrokovanja etičkih nedoumica koje se povezuju s diskriminacijom u "slobodnoj" trgovini. Ekonomska teorija, točnije Heckscher-Ohlinov model, može nam dati zaključke na tom tragu. Svaka pojedina zemlja kao cjelina ima koristi od uključivanja u međunarodnu trgovinu, ali unutar zemalja neki sektori i neki ekonomski subjekti mogu trpjeti štetu. Dakle, odgovor na spomenuto pitanje nije ograničavanje trgovine, nego pravednija distribucija probitaka od trgovine kroz adekvatan i pošten porezni sustav. Redistribucija je u tom slučaju važan faktor u razumijevanju ciljeva vanjske trgovine. Ako se probici od trgovine nepravedno raspodjeljuju među članovima društva, ne samo da to često dovodi do zaključka da politička elita tako pogoduje određenim industrijama ili čelnicima istih industrija, nego se mijenja i biračko tijelo, koje prepoznaje takve malverzacije kao nešto negativno, te naš "srednji glasač" iz teorema o srednjem glasaču mijenja svoj izbor. Uz spomenuto, širenje strukovnoga obrazovanja, izučavanje specifičnih vještina koje zahtijevaju poslodavci, prekvalifikacija ili preseljenje iz područja s nižim ekonomskim rastom u područja s većim ekonomskim rastom, a time i većom ponudom poslova, također mogu utjecati na smanjenje stope nezaposlenosti bez lišenja države brojnih pozitivnih učinaka koje nosi slobodna trgovina.

Do 2016. godine prevladavao je stav o tzv. "demokratskom miru” ili "kapitalističkom miru", koji je bio temeljen na međuovisnosti SAD-a i Kine kao ključnom uvjetu prevencije trgovinskih sukoba. Nakon ulaska u Svjetsku trgovinsku organizaciju Kina je postala odgovorni sudionik na međunarodnom tržištu preuzimajući dio tržišta od SAD-a, što je rezultiralo smanjenjem siromaštva u toj zemlji te stvaranjem osnova za postupnu buduću demokratizaciju zemlje. Takvi bi trendovi posljedično pozitivno utjecali na svjetski poredak i ljudska prava. Poticanje trgovinskoga rata uzrokovalo bi smanjenje životnoga standarda za kineske, ali i američke građane koji ovise o trgovinskom miru, što bi se moglo smatrati neetičnim (Gvosdev, 2019).

Protuargument toj tezi bio bi stav nekih autora da je Kina ulaskom u Svjetsku trgovinsku organizaciju počela izvoziti karakteristike domaćega (neetičkoga) režima, a pritom ubrzala stjecanje ekonomskih resursa te političke i trgovinske moći. Zato bi ograničavanje trgovinskih tokova između SAD-a i Kine značio uklanjanje prešutne potpore kineskomu režimu, koji se suprotstavlja američko- 
mu sustavu vrijednosti, ali i umanjuje ekonomske i tehnološke napretke kojima Kina postaje sve konkurentnija SAD-u. S toga bi stajališta započinjanje trgovinskoga rata bilo donekle etično, ako uzmemo u obzir da su tu prioriteti održavanje američkih vrijednosti i konkurentnost američke ekonomije (Wight, 2018).

Također, Svjetska trgovinska organizacija trenutno je bez aktivnoga djelujućega Odbora za rješavanje trgovinskih sporova zbog odluke SAD-a da se ne odobre novi članovi spomenutoga odbora nakon što je nekima istekao mandat. Odbor sačinjava sedam članova, a minimalno tri potrebna su kako bi se donijele odluke o rješavanju trgovinskih sporova. U prosincu 2019. godine istekli su mandati dvaju članova, te danas Odbor nema minimum članova za izglasavanje važnih odluka, nego je jedina članica i predsjednica Hong Zhao, kojoj mandat istječe krajem studenoga 2020. godine. S obzirom na to, nema ni organizacije koja bi bila sudac u međunarodnim trgovinskim sporovima (uključujući i onaj između SAD-a i Kine), pri čemu se mnogi pribojavaju povratka u razdoblje trgovinskih barijera i hladnoga rata prije 1990-ih.

Naznake smirivanja sukoba počele su se nazirati u siječnju 2020., kada su Kina i SAD potpisale tzv. "prvu fazu" trgovinskoga sporazuma kojim se Kina obvezuje kupovati više od američkih proizvođača. Ekonomisti i politolozi sa sumnjom gledaju na taj događaj, jer se time Kina odmiče od svojega političkoga modela državno vođenoga gospodarstva. Upitno je koliko će se u sljedećim fazama, ako ih bude, SAD i Kina moći odreći vlastitih vrijednosti, interesa, a time i politika, kako bi postignule kompromis. Vanjski faktor koji bi mogao utjecati na pogoršanje odnosa kineskoga i američkoga gospodarstva širenje je pandemije Covid-19. Tvrtke, a pogotovo one globalne, u ovom trenutku brinu o svojim lancima opskrbe dugoročno. Primjerice, Apple je u veljači 2020. objavio da će svjetska opskrba mobitelima iPhone zbog pandemije biti privremeno ograničena, što ce imati kratkoročni učinak na globalni BDP. Nešto ranije, u ljeto 2019. godine, predsjednik Trump izdao je naputak Appleu da zatvori sve tvornice u Kini, što opskrbu u srednjem roku izlaže još većim neizvjesnostima.

Svaka država ima pravo donijeti i provoditi vlastitu međunarodnu, a time i trgovinsku politiku. Također, svaka država ima obvezu štititi interese svojih građana. Glavna je dvojba upitnost moralnosti međunarodne trgovinske politike SAD-a, koja poboljšava uvjete poslovanja nekih domaćih proizvođača, ali nanosi veliku štetu američkim potrošačima, kojih je daleko više, te remeti svjetski poredak i trgovinske sporazume, a time i međunarodnu trgovinu.

\section{Zaključak}

U 2018. godini SAD je uvezao dobra i usluge u vrijednosti 3,1 trilijuna USD, a izvoz je SAD-a istovremeno iznosio 2,5 trilijuna USD, zbog čega se trgovinski deficit zemlje nastavio povećavati (Bown, 2019). Činjenica da SAD uvozi više proizvoda iz Kine nego što Kina uvozi iz SAD-a zasigurno je jedan od razloga uvođenja carina od strane SAD-a prema Kini, ali i drugim zemljama. Trgovinski manjak SAD-a ne može se objasniti samo preprekama na tržištima glavnih 
trgovinskih partnera. Jedan od razloga za takva kretanja SAD vidi u institucionalnom slabljenju domaće valute Kine, što zemlji neopravdano omogućuje veću konkurentnost na globalnom tržištu. Neke razloge za vlastiti trgovinski deficit SAD često ne želi javno apostrofirati, a odnose se na činjenicu da investicije u SAD-u bitno nadilaze nacionalnu štednju. Također, veliki dio potreba za inozemnim kapitalom odnosi se na financiranje proračunskoga manjka SAD-a, pri čemu porezna reforma pojačava ekspanzivnu fiskalnu politiku SAD-a. Nerijetko u SAD-u nisu usklađeni ni ciljevi fiskalne i trgovinske politike. Nametnutim trgovinskim ograničenjima SAD je stavio kineske izvoznike u nepovoljniji položaj, no istovremeno nije poboljšao domaću gospodarsku situaciju. Veće uvozne cijene u SAD-u povećale su cijene domaćih gotovih proizvoda iznad tržišnih cijena, što je dovelo do pada potražnje. Istovremeno je djelomično pogoršano i stanje na američkom tržištu kapitala.

Usprkos očekivanomu ublažavanju i potencijalnomu završetku trgovinskoga rata, a vezano uz potpisivanje trgovinskoga sporazuma između SAD-a i Kine u siječnju 2020., vrijeme će pokazati koliko će ograničavajućih trgovinskih mjera i dalje ostati na snazi, odnosno kako će se u budućnosti razvijati američka i kineska trgovina. Pritom ce razvoj događaja u SAD-u i Kini utjecati ne samo na dinamiku domaćega, nego i stopu rasta svjetskoga gospodarstva. Završetak trgovinskoga spora otklonio bi pritom brojne etički dvojbene odluke, koje izravno i neizravno utječu na životni standard ljudi diljem svijeta, ali i, potencijalno, nastavak promicanja ljudskih prava.

\section{Literatura}

Bown, Chad P. (2018a). Europe is pushing back against Trump's steel and aluminum tariffs. Here's how. The Washington Post (ožujak). URL: https://www.washingtonpost. com/news/monkey-cage/wp/2018/03/09/europe-is-pushing-back-against-trumpssteel-and-aluminum-tariffs-heres-how/ (12.03.2020.)

Bown, Chad P. (2018b). Why the U.S. Needs Allies in a Trade War Against China. Harvard Business Review (prosinac). URL: https://hbr.org/2018/12/why-the-u-s-needsallies-in-a-trade-war-against-china (02.04.2020).

Bown, Chad P. (2018c). US-China TradeWarTariffs: An Up-to-Date Chart. Peterson Institute for International Economics. URL: https://www.piie.com/research/piie-charts/ us-china-trade-war-tariffs-date-chart (29.03.2020.)

Bown, Chad P.; Kolb, Melina (2020). Trump's Trade War Timeline: An Up-to-Date Guide. PIIE. URL: https:/www.piie.com/blogs/trade-investment-policy-watch/trumptrade-war-china-date-guide (1.4.2020.)

Cerutti, Eugenio; Gopinath, Gita; Mohommad, Adil (2019). The Impact of US-China Trade Tensions. IMFBlog (23. svibnja). URL: https://blogs.imf.org/2019/05/23/theimpact-of-us-china-trade-tensions/ (25.06.2020.)

ECB (2018). Boxes: Implications of rising trade tensions for the global economy. Economic Bulletin, 3. izdanje. URL: https://www.ecb.europa.eu/pub/pdf/other/ecb.ebbox 201803_01.en.pdf (12.04.2020.)

Editorial Board (2019). Trade war becomes currency war. Wall Street Journal (5. kolovoza). URL: https://www.wsj.com/articles/trade-war-becomes-currency-war-11565047706 (09.04.2020.) 
Egger, Peter; Zhu, Jiaqing (2019). The US-Chinese Trade War: An Event Study of Stock-Market Responses. 70th Economic Policy Panel Meeting. URL: https://www. economic-policy.org/wp-content/uploads/2019/09/998_US-China-Trade-War.pdf (20.04.2020.)

Egger, Peter; Zhu, Jiaqing (2020). Stock market responses triggered by the US-China trade war. VoxEu (9. siječnja). URL: https://voxeu.org/article/stock-market-responses-triggered-us-china-trade-war (20.04.2020.)

Evans, Olaniyi (2019). The Effects of US-China Trade War and Trumponomics. Forum Scientiae Oeconomia, 7, 47-55.

Grosdev, Nikolas (2019). Ethical considerations in a trade war with China. Ethics and International Affairs (kolovoz). URL: https://www.ethicsandinternationalaffairs. org/2019/ethical-considerations-in-a-trade-war-with-china/ (01.04.2020.)

ITC (2020). International trade in goods - Imports 2001-2019. International Trade Center. URL: https://www.intracen.org/itc/market-info-tools/statistics-import-countryproduct/ (25.10.2020.)

Johnson, Keith (2019). How Trump may finally kill WTO. Foreign Policy (9. prosinac). URL: https:/foreignpolicy.com/2019/12/09/trump-may-kill-wto-finally-appellatebody-world-trade-organization/ (20.04.2020.)

Krugman, Paul R.; Obstfeld, Maurice (2009). Međunarodna ekonomija. Zagreb: Mate.

Li, Chunding; He, Chuantian; Lin, Chuangwei (2018). Economic Impacts of the Possible China-US Trade War. Emerging Markets Finance and Trade, 54, 1557-1577.

Liu, Tao; Woo, Wing Thye (2018). Understanding the U.S.-China Trade War. China Economic Journal, 11, 319-340.

Northam, Jackie (2018). Why President Trump Hates Canadian Dairy - And Canada Insists On Protecting It. NPR (10. srpnja). URL: https://www.npr. org/2018/07/10/627271410/why-president-trump-hates-canadian-dairy-and-canada-insists-on-protecting-it? $\mathrm{t}=1587289375615$ (03.04.2020.)

Putz, Adam; Mirhaydari, Anthony; Clark, Kate (2018). How Trump's Trade War With China Will Affect US Investment Market. Seattle Business. URL: https://www.seattlebusinessmag.com/finance/how-trumps-trade-war-china-will-affect-us-investment-markets (06.04.2020.)

Statista (2019). United States goods trade deficit with China from 2013 to 2020 (in billion U.S. dollars). Statista. URL: https://www.statista.com/statistics/939402/us-china-trade-deficit/ (23.04. 2020.)

Tam, Pui Sun (2019). Global impacts of China-US trade tensions. The Journal of International Trade \& Economic Development, 29(5), 510-545.

USTR (2019). United States Trade Representative, $\$ 300$ Billion Trade Action (Proposed List 4). URL: https://ustr.gov/issue-areas/enforcement/section-301-investigations/section-301-china/300 - billion-trade-action (24.03.2020.)

USTR (2020). United States Trade Representative, United States-Mexico-Canada Agreement. URL: https://ustr.gov/trade-agreements/free-trade-agreements/united-states-mexico-canada-agreement (27.03.2020.)

Wight, Jonathan B. (2018). Trade wars. Economics and Ethics (6. ožujka). URL: https:// www.economicsandethics.org/2018/03/trade-wars.html (12.04.2020.)

Wong, Dorcas; Chipman Koty, Alexander (2020). The US-China Trade War: A Timeline. China Briefing (25. kolovoz). URL: https://www.china-briefing.com/news/the-uschina-trade-war-a-timeline/ (02.03.2020.) 


\section{USA-China Trade War}

Causes, Effects and Ethical Aspects

Anja Tkalčević*, Iva Matić**, Josipa Šegota***

\section{Summary}

At the beginning of 2018, the USA imposed a variety of tariffs and import duties. Since China was most affected by these taxes, the trade war began. The total value of US customs tariffs imposed on Chinese goods is worth US\$ 550bn, while the total value of Chinese customs tariffs imposed on US goods amounts to US\$185bn. Late in 2019, the end was looming - China committed to importing US\$200bn worth of US goods over the next two years, while the US agreed to "halve" the tariffs on Chinese goods. One of the reasons behind the war is the fact that China exports much more to the US than it imports, while the reverse is true for the US. The US claims that China's inadequate position in the WTO and manipulations of the RMB/USD exchange rate are to blame for its vast trade deficit. Another reason is the realization that through acquisitions and takeovers, China is acquiring advanced technology for which it has not been paying a fair corresponding price. However, higher import prices helped some USA corporations which compete with foreign exports, but at the same time increased domestic production costs and reduced the purchasing power of American households, thus negatively affecting consumption, investment and employment. This in turn amplified economic uncertainty and reduced potential economic growth in the long run. The ethics of the US decision to protect certain domestic companies from international competition, while at the same time inflicting greater costs on other economic entities (notably consumers) in the USA and around the globe are difficult to defend.

Key words: trade war; USA; China; protectionism

* Anja Tkalčević, MBA. Zagreb School of Economics and Management. Address: Vukasovićeva 1, 10000 Zagreb, Croatia. Croatian Financial Services Supervisory Agency (HANFA). Address: Ul. Franje Račkog 6, 10000 Zagreb, Croatia. E-mail: aristic@zsem.hr. The opinions expressed in this text are the personal opinions of the authors and do not necessarily reflect the opinions of the agency.

** Iva Matić, Zagreb School of Economics and Management. Address: Vukasovićeva 1, 10000 Zagreb, Croatia. E-mail: imatic@student.zsem.hr

*** Josipa Šegota, bacc. oec., Zagreb School of Economics and Management. Address: Vukasoviceeva 1, 10000 Zagreb, Croatia. ZŠEM — Business Academy d.o.o. Address: Jandrićeva 12, 10000 Zagreb, Croatia. E-mail: jsegota@zsem.hr 